\title{
ANALISIS KARAKTERISTIK AKUIFER KARST DENGAN UJI PERUNUTAN DAN PEMETAAN GUA
}

\author{
Romza Fauzan Agni 1 $^{*}$ \\ Ahmad Cahyadi ${ }^{2}$ \\ Afid Nurkholis ${ }^{3}$ \\ ${ }^{1}$ Karst Research Group Fakultas Geografi UGM, romza.fauzan@gmail.com \\ ${ }^{2}$ Karst Research Group Fakultas Geografi UGM, ahmadcahyadi@geo.ugm.ac.id \\ ${ }^{3}$ Karst Research Group Fakultas Geografi UGM, afidnurkholis@gmail.com \\ *corresponding author: romza.fauzan@gmail.com
}

\begin{abstract}
ABSTRAK
Karakteristik hidrogeologi karst penting dilakukan guna mendukung perencanaan pengelolaannya di masa depan. Namun demikian, lorong-lorong perguaan di daerah karst tidak semuanya dapat dijangkau karena berbagai kendala seperti penyempitan lorong sehingga manusia sudah tidak dapat memasukinya dan adanya lorong gua yang penuh dengan air, sehingga pendefinisian sistem hidrogeologi karst sulit dilakukan. Penelitian ini dilakukan di Gua Pindul dan sekitarnya yang terletak di Kecamatan Karangmojo, Kabupaten Gunungkidul. Tujuan penelitian ini adalah : (1) menganalisis hidrokemograf uji perunutan dari percabangan sistem Gua Pindul, (2) mengetahui morfometri Gua Tanding sebagai percabangan baru dari sistem Gua Pindul. Metode yang digunakan dalam penelitian ini menggunakan metode survei yang terbagi dalam beberapa tahap meliputi tahap persiapan, tahap kerja lapangan, dan tahap pasca lapangan. Tahap persiapan meliputi pemilihan lokasi penelitian dan pemilihan lokasi untuk dilakukan injeksi zat perunut. Tahap kerja lapangan meliputi pemasangan fluorometer di Gua Pindul, injeksi zat perunut di sinking stream Kedungbuntung, dan pemetaan Gua Tanding. Tahap pasca lapangan adalah analisis hidrokemograf uji perunutan dan pengolahan data pemetaan gua. Hasil penelitian menunjukkan bahwa : (1) terdapat konektivitas antara sinking stream Kedungbuntung dan Gua Pindul yang terdeteksi pertama kali 408 menit setelah dilakukan injeksi zat perunut serta dari hidrokemograf terlihat adanya beberapa puncak yang menandakan adanya pemecah aliran, (2) dari pemetaan Gua Tanding dapat diketahui bahwa panjang lorong 375.9 meter, volume gua sebesar $17781.9 \mathrm{~m}^{3}$, rata-rata diameter lorong gua adalah 6.9 meter.
\end{abstract}

Kata kunci : sistem Gua Pindul, Gua Tanding, uji perunutan, pemetaan gua. 


\section{PROCEEDING, KONGRES \& PERTEMUAN ILMIAH TAHUNAN KE-2 \\ PERHIMPUNAN AHLI AIRTANAH INDONESIA (PIT-PAAI) \\ 13 - 15 SEPTEMBER 2017, YOGYAKARTA}

\section{Pendahuluan}

Karst merupakan suatu bentanglahan yang memiliki sistem hidrologi dengan ciri khas tersendiri. Bentanglahan ini tercipta dari batuan yang mudah larut, seperti batu gamping, dolomit, gypsum, halit, dan konglomerat. (Karimi, 2012). Bentukan-bentukan yang dapat ditemui di bentangalam karst sangat bervariasi, akan tetapi karakteristik komponen karst secara umum ada 5 hal yakni adanya karren atau lapies, adanya cekungan tertutup atau doline, ditemukan adanya gua dan sistem perguaan, adanya aliran permukaan yang hilang menjadi aliran bawahtanah atau sinking stream, ditemukan adanya mataair dengan debit yang besar. (Gilli, 2015). Indonesia memiliki wilayah karst hampir sekitar $140.000 .000 \mathrm{~km}^{2}$ dari luas total daratan Indonesia. Tersebar hampir di seluruh pulau-pulau besar Indonesia seperti Karst Gunungsewu, Karst Tuban, Karst Cibinong di Jawa, Karst Sangkulirang-Mangkalihat di Kalimantan Timur, Karst Maros di Sulawesi Selatan, Karst Nusa Tenggara dan Karst Papua. Variasi bentuklahan pun dapat terlihat pada setiap kompleks karst yang akibat variasi proses dan faktor pembentuk daerah karst tersebut. (Haryono, 2011).

Permukaan bumi yang tidak diselimuti es dan dapat dijumpai batuan karbonat hanya sebesar $12 \%$ saja, serta $7 \%$ hingga $10 \%$ dari luasan tersebut merupakan bentukan karst. (Ford dan William, 2007). Air hujan yang jatuh pada kawasan karst akan masuk ke dalam pori-pori batuan karbonat penyusun bentuklahan karst yang selanjutnya terjadi proses pelarutan. Porositas batuan karbonat yang semula kecil dalam jangka waktu tertentu akan berkembang menjadi lebih besar dan akan saling berhubungan antara bagian yang satu dengan bagian yang lain. Hasil dari proses pelarutan ini adalah terbentuknya bentukanbentukan eksokarst maupun endokarst.

Sistem hidrologi karst menjadikan minimnya akumulasi cadangan air permukaan yang dapat dimanfaatkan, tapi disisi lain hilangnya air pemukaan dan aliran permukaan yang langsung masuk ke dalam tanah menjadikan akuifer karst memiliki potensi sumberdaya air yang cukup tinggi terutama dari segi kuantitas. Ketersediaan air yang ada didalam tanah ini bisa dikatakan sebagai cadangan airtanah pada bentuklahan karst. Akan tetapi lokasinya yang jauh dari permukaan dan perlu pengelolaan secara teknis dalam pemanfaatannya sehingga potensi airtanah yang melimpah ini akan sia-sia karena tidak termanfaatkan secara optimal bahkan di beberapa tempat menjadi terbuang percuma karena muara aliran air langsung bermuara di laut.

Sungai Bawah Tanah (SBT) merupakan hasil bentukan proses pelarutan. Aliran sungai bawah tanah ini jauh lebih berkembang dari pada aliran sungai permukaan pada bentanglahan karst. Terbentuknya sungai bawah tanah tidak terlepas dari terbentuknya gua-gua karst. Oleh Palmer (2007) disebutkan bahwa gua merupakan bentukan rongga kosong di bawah tanah hasil pelarutan batuan yang soluble dengan ukuran yang cukup besar sehingga memungkinkan manusia untuk bisa memasukinya. Keberadaan gua-gua karst yang saling terhubung satu sama lain menjadikannya sebagai sistem perguaan, kemudian sistem perguaan ini ketika terisi oleh air maka menghasilkan sungai bawah tanah. (Kusumayudha, 2005). 


\section{PROCEEDING, KONGRES \& PERTEMUAN ILMIAH TAHUNAN KE-2 \\ PERHIMPUNAN AHLI AIRTANAH INDONESIA (PIT-PAAI) \\ 13 - 15 SEPTEMBER 2017, YOGYAKARTA}

\section{Metode Penelitian}

\subsection{Uji perunutan}

Tahap pertama sebelum melakukan perunutan sungai bawahtanah adalah survey lapangan dengan melakukan pemetaan sebaran lokasi mulut gua, ponor, sinking stream dan persebaran mataair. Penuangan zat perunut dilakukan di sinking stream Kedungbuntung yang diprediksi bahwa aliran permukaan yang tertelan menjadi aliran bawah permukaan ini akan muncul kembali di Gua Pindul.

Uji perunutan merupakan metode yang tepat untuk penyelidikan asal muasal, pergerakan, dan muara dari aliran airtanah tersebut. Metode perunutan sangat tepat diaplikasikan di daerah karst. Dalam bidang hidrogeologi, perunut menggunakan bahan yang larut dalam air serta ditandai dengan bahan yang dapat diidentifikasi. Dua jenis bahan perunut yang sering digunakan adalah pewarna fluorescent dan garam. (Benischke, dkk, 2007).

Langkah-langkah yang dilakukan dalam mempersiapkan uji perunutan ini adalah:

1. Mengatur logger fluorometer, dengan konfigurasi sebagai berikut :

-SR : interval waktu perekaman yang diinginkan, dengan ketentuan sebagai berikut :

\begin{tabular}{|l|c|c|c|c|c|c|c|c|}
\hline display & $\mathbf{0}$ & $\mathbf{1}$ & $\mathbf{2}$ & $\mathbf{3}$ & $\mathbf{4}$ & $\mathbf{5}$ & $\mathbf{6}$ & $\mathbf{7}$ \\
\hline second & 2 & 3 & 10 & 30 & 1 & 2 & 5 & 15 \\
& $\mathrm{sec}$ & $\mathrm{sec}$ & $\mathrm{sec}$ & $\mathrm{sec}$ & $\mathrm{min}$ & $\mathrm{min}$ & $\mathrm{min}$ & $\min$ \\
\hline
\end{tabular}

- ST : perintah untuk mulai dan berhenti melakukan perekaman, dengan ketentuan kode "0" untuk mulai akuisisi data, dan "1" untuk perintah stop.

- Number 1 : Selalu bernilai “0” jika SR > 1.

- Number 2 : Diisikan kode " 0 " ketika perekaman tidak terhubung dengan laptop, atau kode "1" ketika perekaman terhubung dengan laptop.

- Number 3 : Diisikan kode "0" untuk menampilkan millivolt, dan kode "1" untuk menampilkan ppb di layar LCD.

- Number 4 : Diisikan kode "0" untuk amplifikasi 1x, dan kode " 1 " untuk amplifikasi 10x.

3. Memasang kabel yang menghubungkan logger dengan instrument air fluorometer.

4. Memasang instrument air fluorometer di air, dengan sensor atau katup yang terbuka menghadap arah aliran.

5. Menyalakan logger dengan cara menghubungkan secara parallel dengan battery 12 Volt.

6. Melakukan penuangan zat perunut di titik injeksi. Adapun kuantitas zat perunut yang diperlukan mengacu pada rumus yang dikemukakan oleh Kass (1998) dalam Goldscheider (2007), yakni : $\mathrm{M}=$ L.k.B , dengan keterangan $\mathrm{M}=$ kuantitas zat perunut yang diperlukan $(\mathrm{kg}), \mathrm{L}=$ jarak dari titik injeksi dengan titik observasi $(\mathrm{km}), \mathrm{k}=$ koefisin zat perunut yang digunakan. Untuk uranine koefisiennya " 1 ". B = faktor kondisi hidrogeologi, untuk daerah karst nilainya sebesar 0,1-0,9.

Pembacaan dan analisis uji perunutan dilakukan dengan menggunakan Software Fluo, yang terdapat dalam satu paket dengan seperangkat alat fluorometer. Langkahlangkahnya adalah sebagai berikut :

1. Menginstall software Fluo.

2. Memberikan perintah "stop" pada logger dengan merubah kode menjadi " 1 ". 


\section{PROCEEDING, KONGRES \& PERTEMUAN ILMIAH TAHUNAN KE-2 \\ PERHIMPUNAN AHLI AIRTANAH INDONESIA (PIT-PAAI) \\ 13 - 15 SEPTEMBER 2017, YOGYAKARTA}

3. Melepas instrument air fluorometer, sekaligus melepas battery nya.

4. Melepas card reader yang terdapat pada logger.

5. Melakukan pembacaan data perekaman di laptop.

6. Menganalisis hidrokemograf uji perunutan

\subsection{Pemetaan gua}

Proses pemetaan gua dilakukan dengan penentuan titik survei. Titik survei ini selanjutnya dikenal dengan sebutan stasiun. Stasiun dapat dibagi kedalam 2 kategori, yaitu fixed station dan floating station (Worthington, 1987 dalam Laksmana, 2016). Sistem survei dalam pengambilan data dengan menggunakan top to bottom, yakni pemetaan dimulai dari mulut gua hingga berlanjut ke lorong akhir sebuah gua. Metode dalam pengambilan data menggunakan Foward Method dengan pembaca alat dan pencatat berada dibelakang sedangkan stasioner berada di depan. Penentuan lokasi stasiun berdasarkan pertimbangan: perubahan arah, perubahan ekstrim bentuk lorong ( 3 dimensi) belokan, turunan, atap turun, perubahan lebar dinding, batas pengukuran (30 m), perubahan elevasi ekstrim (pitch, climb), temuan-temuan penting misalnya ornamen khusus dan litologi.

\section{Data}

Penelitian ini menghasilkan 2 data, yakni data hidrokemograf uji perunutan yang merupakan cerminan dari karakteristik akuifer karst yang tidak dapat diakses dari titik injeksi di sinking stream Kedungbuntung hingga titik pemantauan di Gua Pindul. Data kedua yang diperoleh adalah model 3D dan karakteristik lorong dari Gua Tanding yang merupakan percabangan baru dari sistem sungai bawahtanah Pindul karena sebelumnya entrance Gua Tanding ini belum ditemukan.

\section{Hasil dan Pembahasan}

\subsection{Karakteristik akuifer karst dari hasil uji perunutan}

Bahan atau zat perunut yang digunakan dalam uji perunutan ini adalah uranine. Alammareen (2010) menjelaskan karakteristik dari uranine ini antara lain:

- merupakan bubuk berwarna merah, yang apabila telah tercampur dengan air akan berwarna hijau;

- tidak berbau dan tidak berbahaya bagi manusia serta lingkungan sekitar;

- merupakan zat perunut yang paling dikenal dan paling sering digunakan, karena memiliki batas deteksi yang rendah (sampai $0,002 \mathrm{mg} / \mathrm{l}$ );

- $\quad$ tidak terserap di mineral lempung yang biasanya terdapat di akuifer karst;

- merupakan zat perunut yang tepat untuk dapat diaplikasikan pada cakupan area yang luas dan jarak yang panjang antara titik injeksi dan titik observasi.

Alat yang digunakan untuk mendeteksi zat perunut ini adalah fluorometer. Pemasangan fluorometer ini diletakkan di Gua Pindul sebagai lokasi menghadang zat perunut yang sebelumnya telah dituang uranine di sinking stream Kedungbuntung. Hasil dari uji perunutan ini adalah kurva hidrokemograf, menunjukkan hubungan antara konsentrasi zat perunut dan waktu yang dicatat oleh fluorometer. Kurva hidrokemograf hasil uji perunutan ini dapat mencerminkan karakteristik aliran airtanah dan struktur jaringan sungai bawahtanah yang tidak dapat diakses. Kurva hidrokemograf ini juga dapat dikatakan sebagai model dari akuifer karst. (Smart, 1988). 


\section{PROCEEDING, KONGRES \& PERTEMUAN ILMIAH TAHUNAN KE-2 \\ PERHIMPUNAN AHLI AIRTANAH INDONESIA (PIT-PAAI) \\ 13 - 15 SEPTEMBER 2017, YOGYAKARTA}

Berdasarkan kurva hasil uji perunutan tersebut menunjukkan hasil positif, yang artinya terdapat hubungan antara sinking stream Kedungbuntung dan Gua Pindul, serta dapat diketahui adanya pemecah aliran yang dapat menjadikan 2 atau lebih puncak hidrokemograf. Hal yang menyebabkan dapat terjadinya 2 atau lebih puncak hidrokemograf antara lain pertama, adanya kolam ( $p o o l$ ) yang dapat menghambat aliran dari titik injeksi hingga titik observasi sehingga sebagian zat perunut dapat langsung lewat dan sebagian lainnya tertahan dalam waktu tinggal tertentu. Kedua, cairan zat perunut melewati beberapa saluran (conduit). Ketiga, cairan zat perunut melewati media conduit, fissure, maupun diffuse disaat yang bersamaan sehingga kecepatannya juga berbeda. Kurva hidrokemograf tersebut menunjukkan adanya sistem berupa conduit dari titik injeksi di sinking stream Kedungbuntung yang tersambung dengan titik observasi di Gua Pindul.

Injeksi zat perunut dilakukan pada tanggal 26 Mei 2017 pukul 08.30 WIB dan mulai terdeteksi di Gua Pindul setelah 408 menit. Fluorometer kemudian dilepas pada tanggal 31 Mei 2017 pukul 18.00 setelah air di Gua Pindul sudah tidak berwarna hijau yang menandakan konsentrasi dari zat perunut telah menghilang. Analisis melalui piranti lunak Fluo dapat diketahui bahwa debit aliran dari titik injeksi hingga titik observasi adalah sebesar $0.091 \mathrm{~m} 3 /$ detik.

\subsection{Karakteristik lorong Gua Tanding}

Morfologi lorong gua baik bentukan besar maupun kecil dapat menggunakan analysis of conduit morphology. Analisis ini memungkinkan untuk mengkarakterisasi kondisi aliran masa lalu dan masa sekarang dalam conduit atau lorong. Ada tiga jenis conduit cross-sections, masing-masing mencirikan suatu jenis aliran saluran yang saat ini masih aktif yaitu vertical shaft (pits), meanders (ngarai berkelok-kelok), dan phreatic conduits. Karakteristik mikromorfologi (smalls form) pada lorong gua dapat untuk menetukan arah aliran pada masa lalu (Gillieson, 2007).

Gua Tanding yang merupakan percabangan sistem bawahtanah Gua Pindul yang baru ditemukan mulut guanya karena aktivitas manusia. Cairan zat perunut yang sebelumnya dituang di sinking stream Kedungbuntung juga terdeteksi di Gua Tanding dengan waktu jeda lebih dari 2 jam, padahal jarak antar keduanya tidak lebih dari 50 meter. Hal ini dimungkinkan bahwa cairan zat perunut menggenang pada suatu kolam ( $p o o l$ ) di lorong perguaan yang tidak diketahui karena sudah tidak dapat ditelusuri.

Gua Tanding dipetakan dengan sistem survei top to bottom, dalam sistem ini arah pengambilan data adalah dari bagian luar gua menuju bagian dalam gua. Pemetaan dimulai dari atau sebelum entrance dilanjutkan ke arah dalam gua. Metode survei pemetaan gua yang digunakan adalah forward method atau metode maju karena posisi pembidik sasaran (shooter) selalu berada di belakang stationer. Setelah melakukan pembacaan alat ukur (leica disto dan klinometer) dan melaporkan hasil pembacaan kepada descriptor, shooter berpindah ke posisi stationer. Setelah titik stasiun ditempati oleh shooter, stationer bergerak kedepan untuk menentukan stasiun berikutnya.

Data pemetaan gua kemudian diolah dengan software Compass untuk menghasilkan penampang 3D nya. Hasil dari statistic cave menunjukkan bahwa panjang lorong 375.9 meter, volume gua sebesar $17781.9 \mathrm{~m}^{3}$, rata-rata diameter lorong gua adalah 6.9 meter, dengan arah lorong Gua Tanding didominasi ke arah barat-utara. 


\section{PROCEEDING, KONGRES \& PERTEMUAN ILMIAH TAHUNAN KE-2 \\ PERHIMPUNAN AHLI AIRTANAH INDONESIA (PIT-PAAI) \\ 13 - 15 SEPTEMBER 2017, YOGYAKARTA}

\section{Kesimpulan}

1. Terdapat konektivitas antara sinking stream Kedungbuntung dan Gua Pindul yang terdeteksi pertama kali 408 menit setelah dilakukan injeksi zat perunut serta dari hidrokemograf terlihat adanya beberapa puncak,

2. Karakteristik Gua Tanding dapat diketahui bahwa panjang lorong 375.9 meter, volume gua sebesar $17781.9 \mathrm{~m}^{3}$, rata-rata diameter lorong gua adalah 6.9 meter, dengan didominasi arah lorong ke barat-utara.

\section{Acknowledgements}

Penelitian ini merupakan bagian dari Hibah Penelitian Unggul Perguruan Tinggi (PUPT) Dikti tahun 2016 yang berjudul "Karakterisasi Hidrologi dan Banjir di Sungai Bawah Tanah Gua Pindul untuk Mendukung Pengelolaan Pariwisata Berkelanjutan Berbasis Manajemen Kebencanaan". Penulis menyampaikan ucapan terimakasih kepada Dikti dan Lembanga Penelitian dan Pengabdian Masyarakat (LPPM) Universitas Gadjah Mada selaku pihak yang mendukung kegiatan penelitian ini. Penulis juga ingin mengucapkan terima kasih untuk pihak-pihak lainnya yang terkait dengan berjalannya penelitian ini.

\section{Daftar Pustaka}

Alammareen, A.M. 2010. Groundwater Exploration in Karst Examples for Shallow Aquifers Using Microgravity Technique in Paderborn-Germany and the Reconnaissance of Deep Aquifers in Catchment of Barada Spring-Syria. Disertasi. Berlin: Fakultät VI - Planen Bauen Umwelt der Technischen Universität Berlin.

Bemmelen, R.W. Van., 1949. The Geology of Indonesia, Vol. 1 A, Government Printing Office, The Hauge.

Benischke, R et.al. 2007. Tracer techniques. Dalam Goldscheider N. dan Drew D. 2007. Methods in Karst Hydrogeology. Leiden: Taylor \& France.

Ford, D.C., dan Williams, P.W. 2007. Karst Geomorhology and Hydrology. London: Chapman and hall.

Gillieson. 1996. Caves : Processes, Development, and Management. Oxford: Blackwell Publishers.

Gilli, E. 2015. Karstology Karst, Caves and Spring. London: CRC Press Taylor \& Francis Group.

Goldscheider et.al. 2007. Method in Karst Hydrogeology. London: Taylor \& Francis Group.

Haryono, E., 2011. Atmospheric carbon dioxide sequestration trough karst denudation processes, Proceeding Asian trans-disciplinary Karst Converence. Yogyakarta: Fakultas Geografi UGM

Karimi, H. 2012. Hydrogeology of Karstic Area. Dalam Kazemi, G.A. 2012. Hydrogeology A Global Perspective. Croatia: In Tech.

Kusumayudha, S.B. 2005. Hidrogeologi Karst dan Geometri Fraktal Daerah Gunungsewu. Yogyakarta: Adicita Karya Nusa.

Laksamana, E.E. 2016. Stasiun nol: Teknik-teknik pemetaan dan survei hidrologi gua Edisi 2. Yogyakarta: ASC.

Palmer, A.N. 2007. Cave Geology. USA: Allen Press.

Rahaningmas, F.S. 2013. Geologi dan hubungan antara fasies karbonat dan jenis porositas terhadap pembentukan Gua Pindul Desa Bejiharjo dan sekitarnya Kecamatan Karangmojo Kabupaten Gunungkidul Daerah Istimewa Yogyakarta. Skripsi. Yogyakarta: Institut Sains \& Teknologi AKPRIND Yogyakarta.

Smart, C.C. 1988. Artificial tracer techniques for the determination of structure of conduit aquifer. Groundwater Journal, Vol. 26 No. 4. 


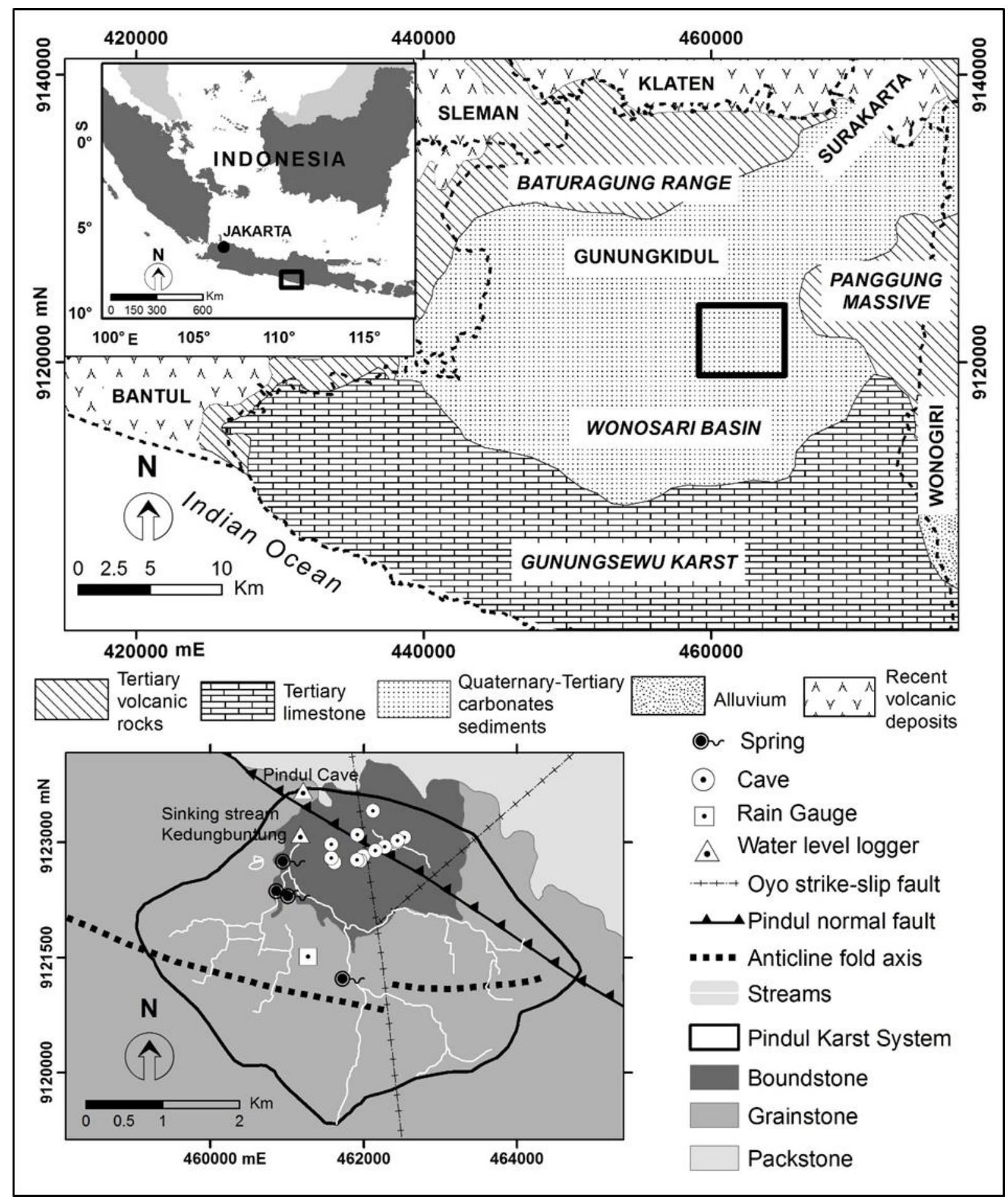

Gambar 1. Peta lokasi penelitian dan daerah tangkapan sistem Gua Pindul (Bemmelen, 1949 dan Rahaningmas 2013) 
PROCEEDING, KONGRES \& PERTEMUAN ILMIAH TAHUNAN KE-2

PERHIMPUNAN AHLI AIRTANAH INDONESIA (PIT-PAAI)

13 - 15 SEPTEMBER 2017, YOGYAKARTA

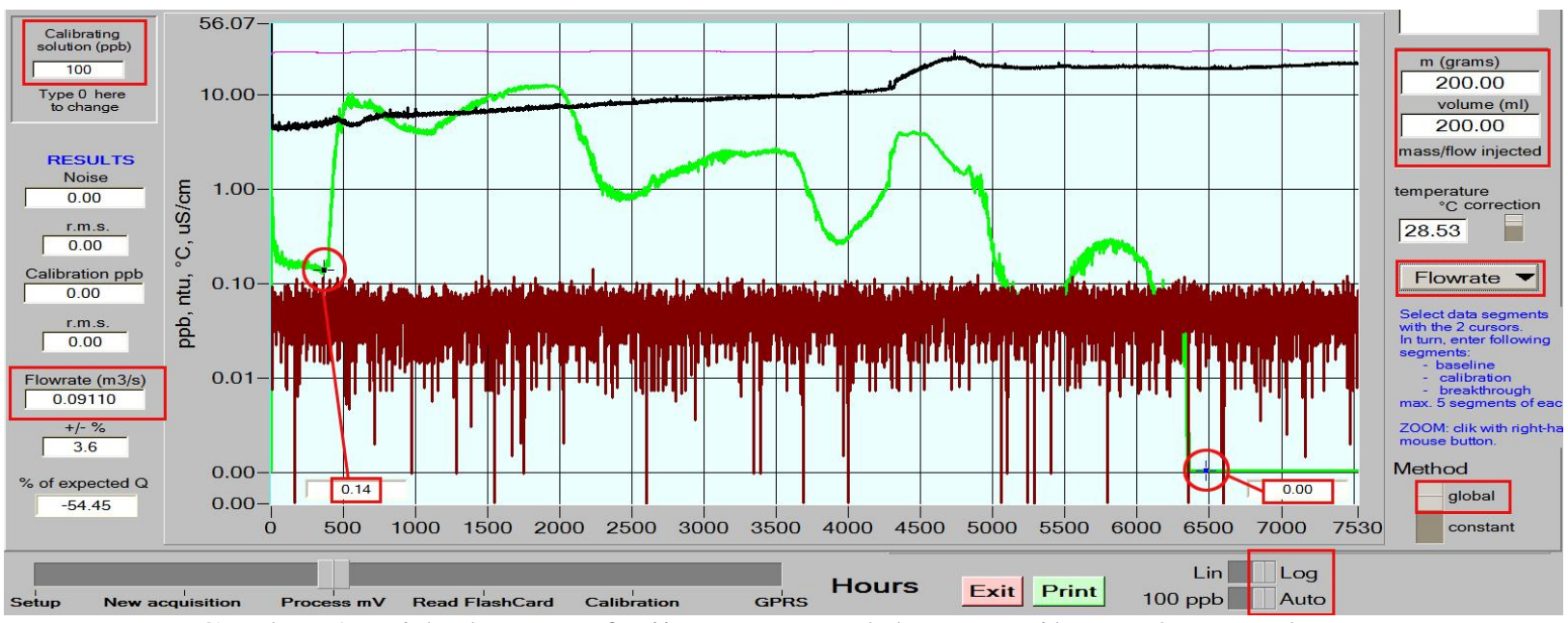

Gambar 2. Hidrokemograf uji perunutan dalam tampilan software Fluo

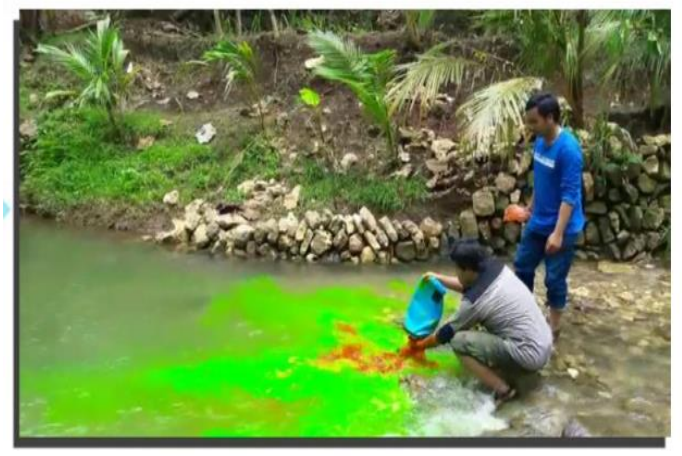

Gambar 3. Penuangan zat perunut

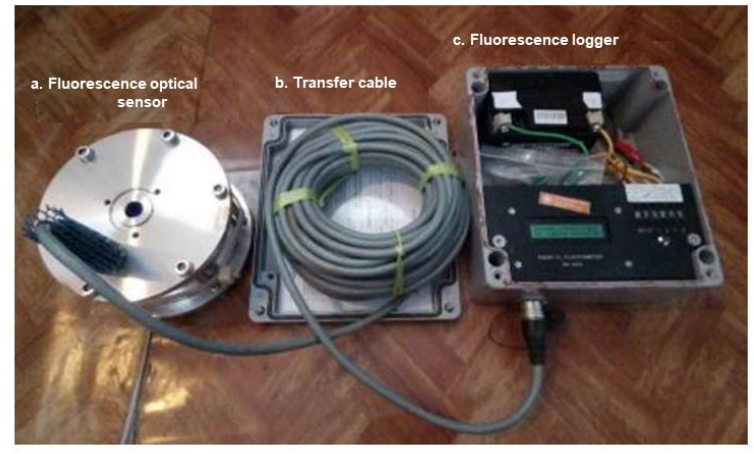

Gambar 4. Seperangkat Fluorometer

\begin{tabular}{|c|c|c|c|c|c|c|c|c|}
\hline dari & ke & jarak & kompas & clino & kiri & atap & bawah & kanan \\
\hline 0 & 0 & 0 & 0 & 0 & 2.449 & 1.104 & 0 & 1.530 \\
\hline 0 & 1 & 9.534 & 257.5 & -2 & 0.728 & 2.74 & 0 & 8.629 \\
\hline 1 & 2 & 19.093 & 344.5 & +2 & 0.9 & 1.2 & 0 & 8.768 \\
\hline 2 & 3 & 20.805 & 295 & -2 & 5.288 & 2.854 & 0 & 3.295 \\
\hline 3 & 4 & 21.694 & 328 & -2 & 0.946 & 3.469 & 0 & 4.771 \\
\hline 4 & 5 & 19.913 & 334 & +1 & 3.636 & 2.936 & 0 & 1.933 \\
\hline 5 & 6 & 23.617 & 335 & -1 & 4.649 & 4.873 & 0 & 4.649 \\
\hline 6 & 7 & 19.986 & 65 & +2 & 1.551 & 4.884 & 0 & 11.492 \\
\hline 7 & 8 & 15.988 & 25 & +1 & 6.563 & 5.104 & 0 & 2.607 \\
\hline 8 & 9 & 26.279 & 30 & +2 & 4.403 & 5.400 & 0 & 2.280 \\
\hline 9 & 10 & 15.435 & 29 & +1 & 7.644 & 7.648 & 0 & 1.281 \\
\hline 10 & 11 & 18.752 & 60 & +1 & 0.632 & 9.594 & 0 & 6.670 \\
\hline 11 & 12 & 25.858 & 55 & +2 & 1.003 & 10.235 & 0 & 3.408 \\
\hline 12 & 13 & 32.753 & 61 & +2 & 7.202 & 9.598 & 0 & 4.969 \\
\hline 13 & 14 & 32.570 & 332 & +1 & 6.313 & 7.643 & 0 & 3.388 \\
\hline 14 & 15 & 25.282 & 338 & -2 & 5.425 & 5.780 & 0 & 2.415 \\
\hline 15 & 16 & 33.529 & 359 & +1 & 1.692 & 4.619 & 0 & 2.557 \\
\hline 16 & 17 & 14.533 & 310 & +1 & 3.516 & 5.770 & 0 & 1.631 \\
\hline
\end{tabular}

Gambar 5. Ceklist pemetaan Gua Tanding 
PROCEEDING, KONGRES \& PERTEMUAN ILMIAH TAHUNAN KE-2

PERHIMPUNAN AHLI AIRTANAH INDONESIA (PIT-PAAI) 13 - 15 SEPTEMBER 2017, YOGYAKARTA
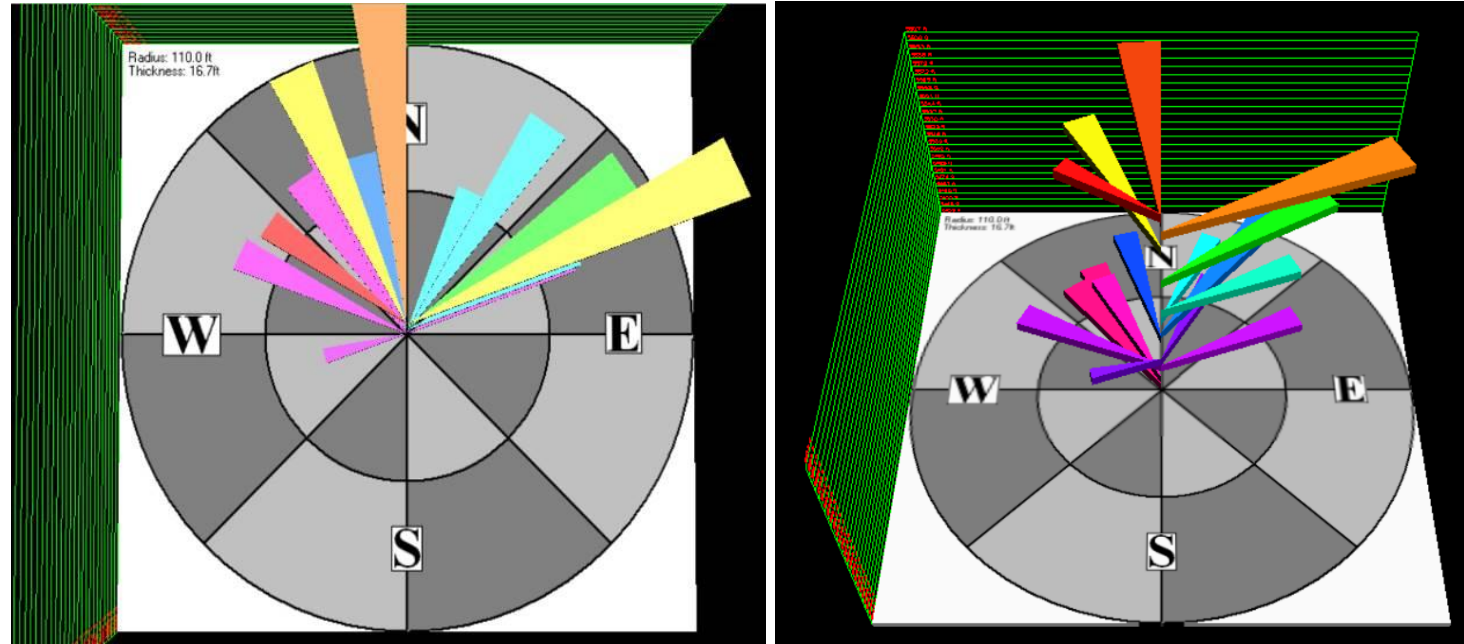

Gambar 5. Rose diagram arah lorong Gua Tanding

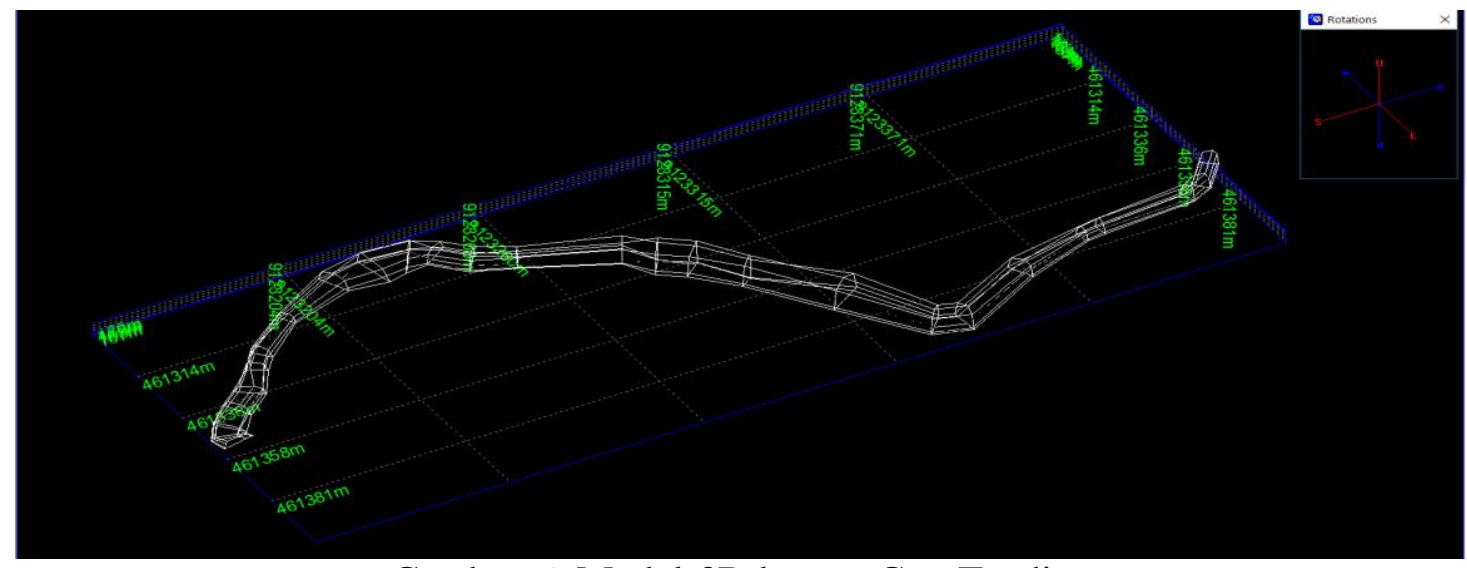

Gambar 6. Model 3D lorong Gua Tanding

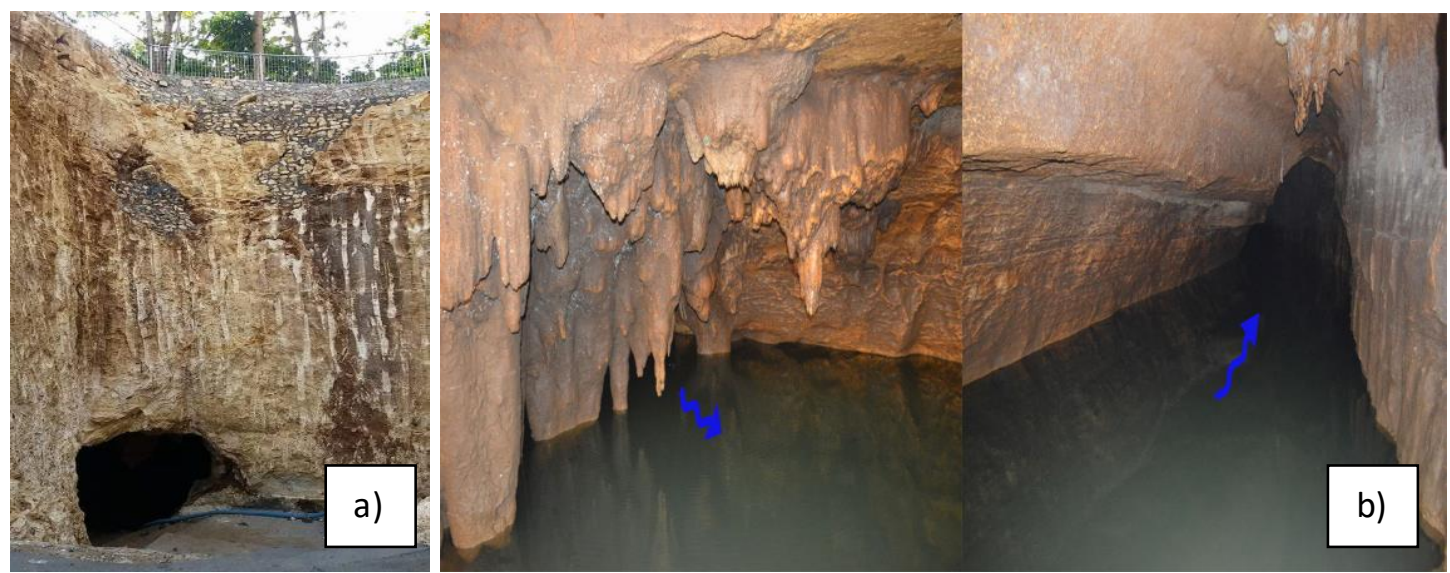

Gambar 8. a) Entrance Gua Tanding, b) Lorong Gua Tanding 